\title{
Effect of wind and tidal advection on distribution patterns of rock crab Cancer irroratus megalopae in Block Island Sound, Rhode Island
}

\author{
Michael Clancy*, J. Stanley Cobb \\ Department of Biological Sciences, 100 Flagg Rd, University of Rhode Island, Kingston, Rhode Island 02881, USA
}

\begin{abstract}
The planktonic period of benthic marine invertebrates can significantly affect distribution patterns of benthic juveniles. In this paper we address the relationship between advection and the subsequent abundance of planktonic megalopae of the rock crab Cancer irroratus in Block Island Sound. Rhode Island (USA), over an 8 yr period. At small scales (several meters distance with samples taken simultaneously), megalopae were found to be similarly distributed; at larger temporal (tens of minutes) and spatial scales (hundreds of meters) megalopae were very patchy, which indicates a complex, highly variable pattern of abundance typical of planktonic systems. Using the receptor-mode trajectory capability of OILMAP, a numerical hydrodynamic model, we detected a significant relationship between the direction of transport prior to collection (as predicted by the model) and the subsequent catch of mogalopae. We argue that rock crab megalopae are often advected tens of kilometers over short time spans and are concentrated on south-facing shores in Block Island Sound. Further, enhanced planktonic delivery to our study area results in large pulses of individuals to the benthos. Directional transport would be an effective larval delivery strategy even ff rock crab megalopae were subject to lower advection, perhaps owing to a deep vertical distribution; a significant relationship between transport direction and collection date was detected even under a lower advective regime.
\end{abstract}

KEY WORDS: Decapod Cancerirroratus Recruitment Advection Numerical hydrodynamic model

\section{INTRODUCTION}

Most benthic marine invertebrates have complex life cycles (Thorson 1950). The dispersive larval period can link patches of relatively sedentary adults into a metapopulation (Roughgarden et al. 1985, 1988). A tradeoff exists between dispersing too far from natal habitat (and settling in inappropriate areas) versus short distance dispersal which may increase competition between newly settled juveniles and adults (Palmer \& Strathmann 1981). Dispersal distances of larvae may be pan-oceanic as they spend months or years in the plankton (Scheltema 1968, 1986), or dispersal may be only a few tens of meters and last a short time (Young 1989, Stoner 1990). Dispersal, coupled with

•E-mail: cji101@uriacc.uri.edu high fecundity and iteroparity are thought to result in highly variable but resilient populations (Chesson 1986, Rothschild 1986, Fogarty et al. 1991).

Although planktonic larvae are small and unable to control horizontal advection, they may use 4 behavioral strategies to affect the distance and direction of travel (Sulkin 1984): (1) larvae may behave like passive particles and demonstrate no directed orientation, (2) larvae may swim vertically to remain in a specific region of the water column (e.g. either in the neuston or epibenthos) (Thorson 1950), (3) larvae may vertically migrate according to diel or tidal cues (Carriker 1951, Forward \& Rittschoff 1994), and (4) larvae may actively swim to adult habitat (Phillips \& McWilliam 1986, Cobb et al. 1989, Rooney \& Cobb 1991). Physical forces that may also affect larval position include winddriven surface currents (Johnson \& Hester 1989, McConnaughey et al. 1992, 1994, Hudon \& Fradette 1993, 
Katz et al. 1994), internal waves (Shanks 1983, 1988) and subtidal transport (Epifanio et al. 1989).

The rock crab Cancer irroratus is a dominant member of the epibenthic community in the Northwest Atlantic and its range extends from Nova Scotia to Virginia and from the intertidal zone to hundreds of meters deep (Williams 1984, Stehlik et al. 1991). In coastal waters adults mate in fall. Females brood their eggs for several months and release their larvae in the late spring or early summer (Sastry 1977). This species is iteroparous and females are highly fecund (Reilly \& Saila 1978, Hines 1991). Little is known of the distribution and abundance patterns of the 5 zoeal stages. Before settling, larvae metamorphose and spend 2 to $3 \mathrm{wk}$ in the plankton as megalopae (Sastry 1977) and during this period they spend at least some time in the neuston (Hudon \& Fradette 1993, Clancy 1995). In the laboratory, megalopae and first stage juveniles settle randomly, and therefore do not actively choose their settlement habitats during or directly after settlement, which corresponds to field observations (Clancy 1995). Consequently, early benthic distribution and abundance patterns in southern Rhode Island may be strongly influenced by processes that affect larval supply.

In this paper we address 2 objectives related to the distribution of rock crab Cancer irroratus megalopae. The first objective is to describe the local distribution and abundance patterns of planktonic megalopae at several temporal and spatial scales using a correlation analysis. The second objective is to use a numerical hydrodynamic model to explore the potential relationship between the abundance of rock crab megalopae in the neuston and their locations at time intervals prior to collection. Our approach was to use independent biological and physical observations, using our planktonic data and the results of the model, to address possible onshore transport. Our null hypothesis for the second objective was no relationship between the abundance of megalopae collected in the neuston and the predicted source location derived from the model simulations.

To address this hypothesis we used the program OILMAP, which was developed to predict the trajectory and fate of oil spills (Spaulding 1988, ASA 1993). OILMAP is designed to predict the trajectory of oil in 2 dimensions and assumes that oil is located primarily in the surface layer of the water column. The model can be run in a trajectory-mode to predict the future location of a mass of oil, or in receptor-mode to predict the most likely location from which oil might have been transported. Our research used the back-calculating capability of OILMAP exclusively. For clarity, all simulations will be referred to as the receptor-mode trajectory simulations (ASA 1993). Using the receptor-mode trajectory capability of OILMAP, we attempted to determine the location of megalopae $5 \mathrm{~d}$ prior to a sampling date. To our knowledge this is the first attempt to understand the temporal abundance of planktonic organisms using independent hydrographic measures produced by OILMAP. This approach is novel because of the limited background knowledge available on Cancer irroratus, especially during its early life history, and because of the utility of OILMAP.

For this paper we address the distribution patterns of rock crab Cancer irroratus megalopae at several different scales. At the smallest scale, we examine the patchiness of megalopae within several meters during the simultaneous towing of 2 nets. Next we determine the patchiness at larger spatial and temporal scales by comparing the catches of megalopae between different sampling stations within a day. Finally using OILMAP, we address the potential link between presumed wind and tidal driven surface currents in an area and the subsequent collection of megalopae over an 8 yr period.

\section{MATERIALS AND METHODS}

Planktonic abundance estimates. Plankton estimates of Cancer irroratus megalopae were made at 3 nearshore stations in Block Island Sound, Rhode Island (USA), from 1986 to 1993: in the Harbor of Refuge (HOR), about $1 \mathrm{~km}$ south of HOR (Bell 4), and $2 \mathrm{~km}$ west of the HOR (Mat). The stations are approximately $2 \mathrm{~km}$ from each other and all are in water 6 to $12 \mathrm{~m}$ deep. All plankton samples were taken using paired rectangular neuston nets $(1.0 \times 0.5 \mathrm{~m})$ with a $0.5 \mathrm{~mm}$. mesh, and towed, one on either side of a small boat, at a speed of approximately 1.5 knots. Nets were fitted with a General Oceanics mechanical flow meter to estimate the total volume of water sampled per tow. Samples were preserved in 5\% formalin in the field and later transferred to $70 \%$ isopropyl alcohol, and the total abundance of $C$. irroratus megalopae per plankton tow was determined. During periods of high megalopal abundance, subsamples were taken using a Folsom plankton splitter to estimate the total abundance in each sample. All densities are expressed as the number of megalopae per $\mathrm{m}^{3}$ of water sampled.

To determine the extent of patchiness in this area, Pearson product moment correlations were performed (Sokal \& Rohif 1981). Correlations were calculated between the abundance of megalopae collected in 2 nets that were towed simultaneously; correlations were also calculated for samples taken on the same day but at 3 different stations (Bell 4, Mat, HOR). Not all years and stations were compared due to a lack of data.

Estimation of larval transport. OLLMAP is a 2dimensional numerical hydrodynamic model that may 
be run in a forecasting or hindcasting mode. The hindcasting (receptor-mode) portion of OILMAP runs a series of individual stochastic spill trajectories that, when taken together, produces a time-dependent, geographically referenced output. Each output is displayed as a funnel-shaped contour with a narrow beginning at the simulation's origin that expands as time progresses. These outputs comment on the source of rock crab megalopae. The model includes shoreline data and does not allow megalopae to pass over land; there is also variable spatial resolution that is determined by the investigator.

OILMAP uses 2 physical variables, wind speed and direction and the average tidal current, in the receptormode trajectory simulations. Wind data were acquired from the National Weather Service office at Green State Airport station in Warwick, Rhode Island. Green State airport is approximately 24 nautical miles due north of the 3 sampling stations and is the closest source of these data. Wind data consist of hourly observations of speed and direction for the months May to September for the years 1986 to 1993. In Block IslandRhode Island Sound, tidal currents predominate. Tides are typically semidiurnal and dominated by the $M_{2}$ (forces due to the moon's gravitational pull) component (Beauchamp \& Spaulding 1978, Knauss 1978). The average predicted tidal speed and direction for the study area were taken from hydrodynamic model simulations of the Buzzards Bay, Rhode Island Sound, Block Island Sound, and Long Island Sound system (Beauchamp \& Spaulding 1978). OILMAP assumes that tides are rectilinear and vary sinusoidally. The direction and magnitude of tidal currents were entered at maximum flood tide ( $3 \mathrm{~h}$ after slack ebb tide) and OILMAP assumed that maximum ebb tide currents were equal and opposite

Input variables in this model are hourly wind direction and magnitude and average hourly tidal currents for the entire Block Island Sound region. Drift factor of buoyant material (found at the surface and perhaps projecting above it) ranges from 4 to $7 \%$ of wind speed (ASA 1993, Youssef \& Spaulding 1993). From planktonic data, we know that rock crab megalopae spend at least some time in the neuston but not at the surface; thus we assumed a drift factor (DF) of $3.5 \%$ which is the value normally used in oil spill simulations (Spaulding 1988, ASA 1993, Youssef \& Spaulding 1993). To approximate transport of megalopae under the influence of a lower advective regime, we used DF $=1.75 \%$ of the wind speed. In all simulations we assumed that megalopal transport was parallel to wind direction and used a $0^{\circ}$ deflection angle.

Before any simulations were conducted, planktonic data were categorized as either a 'low' density (0 to 10 megalopae $\mathrm{m}^{-3}$ ) or 'high' density (>10 megalopae $\mathrm{m}^{-3}$ ) day. We selected 86 dates from the 8 -year time series After categorizing the plankton data, we started a simulation on 1 of the selected dates and used the receptor-mode of OILMAP, which generated a geographically referenced output of proposed transport. All simulations were run for $5 \mathrm{~d}$ with each output predicting the source from which plankton megalopae were advected. Each 5 d simulation was divided into 1, 2 and $3-5$ d sections. An average vector was drawn for each simulation to represent the average direction and magnitude of the proposed transport.

The study area was divided into 4 regions according to their position relative to the plankton sampling stations: (1) West-Southwest (W-SW), (2) Southwest (SW), (3) South-Southeast (S-SE) and (4) East-Northeast (E$\mathrm{NE}$ ). Using these regions as references, we then classified the average direction of each simulation according to where its source was located. Each receptor-mode trajectory simulation was treated as a single observation. We standardized observed frequencies to the largest region, E-NE, because the surface areas of each region differed. Observed, standardized, frequencies were then compared to expectations of random transport using separate $G$-tests of independence conducted on 'high' and 'low' megalopae density dates and assuming high $(D F=3.5 \%)$ and low $(D F=1.75 \%)$ transport (Sokal \& Rohlf 1981).

\section{RESULTS}

\section{Spatial and temporal distribution}

Average daily abundance of neustonic rock crab Cancer irroratus megalopae shows considerable interannual variation in the timing and the extent of peaks (Fig. 1). In 4 of the 8 years (1988 to 1990 and 1992) peak megalopal abundance occurred in the end of June (Fig. 1c, d, e and g). In the first 2 sampling years (1986 and 1987), peaks occurred early in June, and in 2 years (1991 and 1993) there was low abundance throughout the summer (Fig. 1f, h). Megalopa abundance oscillates between high and low densities, with peaks having a generally short duration, and during 5 of 8 years $(1986$, 1987, 1988, 1990, 1992) there were 2 pulses (Fig. 1)

The results for the correlation analysis suggest considerable patchiness at a scale of 1 to $2 \mathrm{~km}$, but not at a scale of several meters (Table 1). Significant productmoment correlations were detected between the abundance of 2 nets towed simultaneously (approximately $3 \mathrm{~m}$ apart). Low correlations were detected between megalopal abundance estimates at different stations on the same day (with the same net) indicating that on larger scales (1 to $2 \mathrm{~km}$ ) megalopae were highly patchy. 


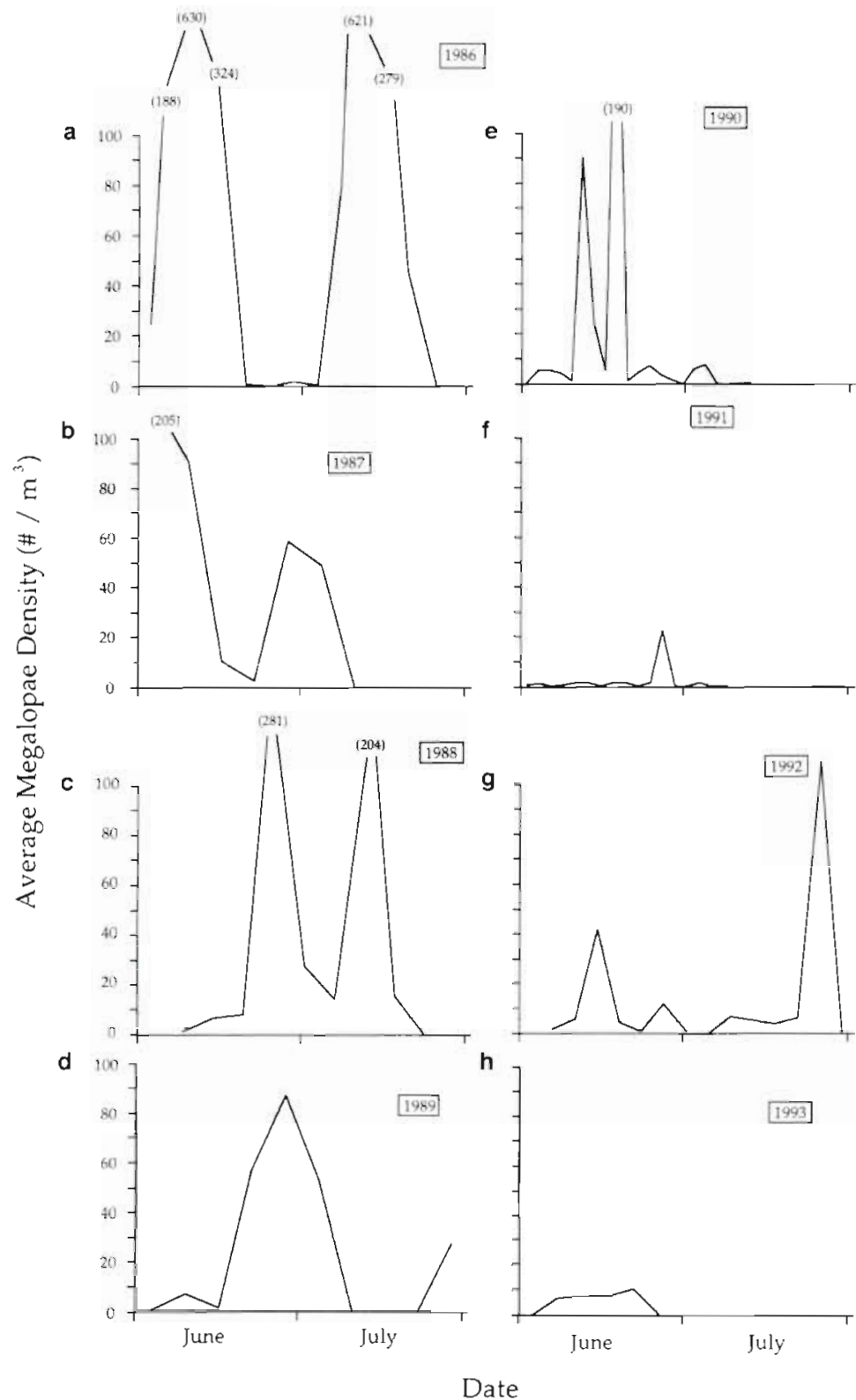

Fig. 1 Average daily abundance of rock crab Cancer irroratus megalopae collected from 3 stations (Bell 4, Matunuck and Harbor of Refuge) in Block Island Sound, Rhode Island, USA, from 1986 to 1993 (a to h respectively)

\section{Estimation of proposed larval transport}

For each receptor-mode simulation, OILMAP generates a proposed transport direction for buoyant material. Each receptor-mode trajectory simulation uses the hourly wind direction and magnitude and average tidal currents during the 5 previous days to predict the most likely area from which megalopae (buoyant material) were advected. Of the 86 simulations conducted, results of two are illustrated in
Fig 2a, b. High megalopa abundance was observed on 24 June 1992 and during the 5 previous days, transport came from $W$-SW and SW of the sampling area. This result suggests onshore advection of megalopae during the 5 days prior to 24 June (Fig. 2a). In contrast, low megalopal abundance was observed on 10 June 1988. The receptormode simulation predicted offshore transport during the 5 previous days E-NE from Bell 4 (Fig. 2b).

Receptor-mode trajectory simulations indicate that surface transport tended to be from the W-SW or SW regardless of drift factor (Table 2a, b). Tidal advection in this area in Block Island Sound is influenced by Long Island Sound and Narragansett Bay (Beauchamp \& Spaulding 1978) and, therefore, advection is presumed to be the product of both wind and tidal advection. During times of high megalopal abundance, observed frequency distributions of predicted receptormode transport are dramatically different than for periods of low megalopal abundance (Table $2 \mathrm{a}, \mathrm{b}$ ). There was a significant relationship between the predicted transport direction and subsequent catch of rock crab megalopae in the neuston during times of high and low abundance (Table 2a, b). Assuming a high drift factor, and a completely neustonic distribution of rock crab megalopae, high densities (>10 megalopae $\mathrm{m}^{-3}$ ) were associated with transport derived from the SW more often than expected (Table 2a). In contrast, when transport originated from the E-NE direction, there was never a high catch of megalopae recorded (Table $2 a, b$ ). High frequency of surface transport originating from the E-NE was observed when megalopal abundance was low (Table 2b). This pattern is consistent with onshore transport resulting in high planktonic megalopae densities and offshore transport resulting in low megalopae densities.

When receptor-mode simulations were conducted assuming a lower drift factor of $1.75 \%$, the pattern of transport was the same as that obtained with a drift factor of $3.5 \%$; OILMAP made similar predictions for the 2 series of simulations (Table $2 \mathrm{~b}$ ). The most obvious difference between the high and low drift simulations is that transport is lower with a lower drift factor. This may indicate that, regardless of the degree of advection, because of the prevailing southwest wind direction at this time of year, rock crab megalopae are often 
Table 1 Comparison of neustonic rock crab Cancer irroratus megalopae abundance estimates. Pearson product moment correlation coefficients $(R)$ are first presented between 2 nets towed simultaneously (Port vs Starboard) from 1990 to 1992. Correlation coefficients are then listed between samples taken at 2 stations (Bell 4 vs Matunuck, Bell 4 vs HOR, HOR vs Matunuck) using the same nets (port or starboard) on the same day. Too few observations were recorded during 1986 to 1989 (and megalopae were virtually absent in 1993) for this analysis to be performed on the entire dataset. Thus only the 1990 to 1992 data was analyzed

\begin{tabular}{|lcccc|}
\hline Comparison & Year & R-value & DF & p-value \\
\hline Port vs Stbd & 1990 & 0.94 & 122 & $\mathrm{p}<0.01$ \\
Port vs Stbd & 1991 & 0.98 & 145 & $\mathrm{p}<0.01$ \\
Port vs Stbd & 1992 & 0.80 & 40 & $\mathrm{p}<0.01$ \\
Bell 4 vs Matunuck & 1990 & & & \\
$\quad$ Port nets & & 0.31 & 42 & $\mathrm{p}=0.05$ \\
$\quad$ Stbd nets & & 0.57 & 40 & $\mathrm{p}<0.05$ \\
Bell 4 vs Matunuck & 1991 & & & \\
$\quad$ Port nets & & 0.09 & 23 & $\mathrm{~ns}$ \\
$\quad$ Stbd nets & & 0.05 & 26 & $\mathrm{~ns}$ \\
Bell 4 vs Matunuck & 1992 & & & \\
$\quad$ Port nets & & 0.01 & 11 & $\mathrm{~ns}$ \\
$\quad$ Stbd nets & & 0.11 & 11 & $\mathrm{~ns}$ \\
Bell 4 vs HOR & & & & \\
$\quad$ Port nets & & 0.39 & 9 & $\mathrm{~ns}$ \\
$\quad$ Stbd nets & & 0.41 & 10 & $\mathrm{~ns}$ \\
HOR vs Matunuck & & & & \\
$\quad$ Port nets & & 0.36 & 11 & $\mathrm{~ns}$ \\
$\quad$ Stbd nets & & 0.24 & 11 & $\mathrm{~ns}$ \\
\hline
\end{tabular}

advected northward towards shore, which results in large pulses of recruitment to the sampling area.

The observed direction and transport vectors from the receptor-mode simulations illustrate the directionality of transport (Fig. 3a, b). Each line represents an average vector, with an associated direction and magnitude, from one receptor-mode simulation (Fig. 3a, b). This illustrates the dramatic difference between predicted receptor-mode transport during high versus low neustonic megalopal abundance periods. Proposed transport directly preceding high megalopal collection was almost exclusively from the W-SW and SW regions (Fig. 3a). In contrast, proposed transport is more evenly distributed during periods of low megalopal abundance (Fig. 3b). If a figure for low transport simulations $(D F=1.75 \%)$ had been included, it would have been identical to Fig. 3a, b, with lower transport.

\section{DISCUSSION}

The planktonic period of benthic marine invertebrates provides individuals the opportunity to disperse to new habitats. Larval dispersal is thought to increase the probability of persistence for a population by increasing individual fitness. The benefit of dispersal is limited because individuals dispersing too far are expected to experience higher mortality than those that disperse shorter distances (Palmer \& Strathmann 1981). Larvae have developed mechanisms to limit dispersal and increase the probability of delivery to appropriate settlement habitat. In the present study of the rock crab Cancer irroratus there was a significant relationship between the direction of predicted advection and the subsequent catch of megalopae.

At small scales (several meters), megalopal abundance was correlated significantly between simultaneously towed nets (Table 1). This indicates that, although we do not know the structure, the temporal coherence, or the spatial extent of the patches, we sampled the same patches. At larger temporal and spatial scales significant patchiness was present, which presumably reflects complex local hydrography (Table 1). The time series ( 8 yr of observations) showed dramatic abundance changes over short time periods (Fig 1). There was also an overall decline in average abundance of rock crab megalopae from 1986 to 1993 with 1991 and 1993 appearing as particularly poor years. This decline may be correlated with a decrease in the adult rock crab population during that same period (H. P Jeffries pers. comm., Clancy unpubl.).

Table 2. Adjusted direction frequencies of proposed surface transport, assuming drift factors $(D F)$ of (a) $3.5 \%$ and (b) $1.75 \%$, using the receptor-mode capability of OILMAP. All simulations were run for $5 \mathrm{~d}$ prior to a collection of rock $\mathrm{crab}$ Cancer irroratus megalopae. Low abundance estimates are defined as $<10$ megalopae $\mathrm{m}^{-3}$ and high abundance estimates as $>10$ megalopae $\mathrm{m}^{-3}$ Transport direction is the location from which megalopae were predicted to have been advected. Drift factor refers to the percent of the wind driven surface transport. Observed frequencies were adjusted for total surface area and scaled to the largest area in the region. Transport was assumed to be parallel to wind direction with an angle of $0^{\circ}$ See Fig. $3 a$, b for more explanation

\begin{tabular}{|c|c|c|}
\hline \multirow{2}{*}{$\begin{array}{l}\text { Transport } \\
\text { direction }\end{array}$} & \multicolumn{2}{|c|}{ Abundance } \\
\hline & Low & High \\
\hline \multicolumn{3}{|l|}{ (a) $D F=3.5 \%$} \\
\hline W-SW & 26 & 15 \\
\hline SW & 3 & 10 \\
\hline S-SE & 7 & 2 \\
\hline \multirow[t]{3}{*}{$E-N E$} & 10 & 0 \\
\hline & $G=24.61$ & 21.09 \\
\hline & $p<0.001$ & 0.001 \\
\hline \multicolumn{3}{|l|}{ (b) $D F=1.75 \%$} \\
\hline W-SW & 15 & 15 \\
\hline SW & 5 & 10 \\
\hline S-SE & 6 & 5 \\
\hline \multirow[t]{3}{*}{ E-NE } & 4 & 0 \\
\hline & $G=9.03$ & 16.43 \\
\hline & $p=0.05$ & 0.05 \\
\hline
\end{tabular}


Short-term and drastic abundance changes in planktonic density are consistent with an exogenous production and subsequent transport of megalopae to our sampling sites (Fig 1). An alternative mechanism to explain such dramatic abundance changes over such a

a

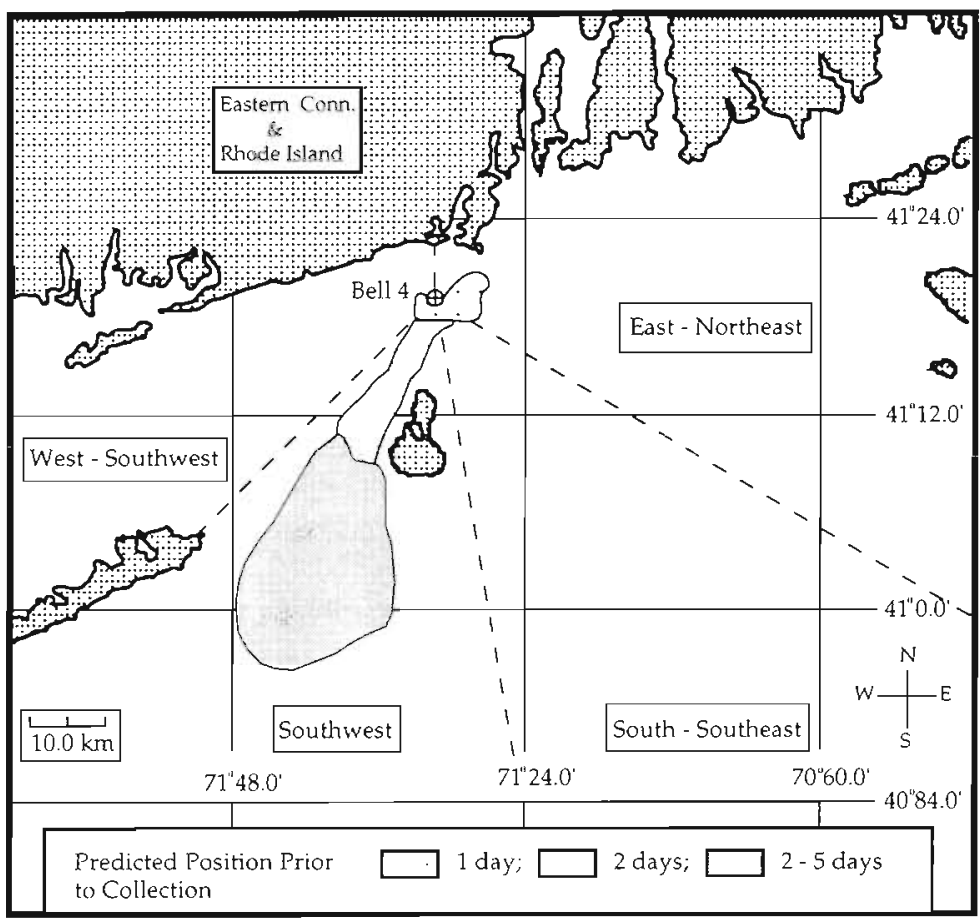

b

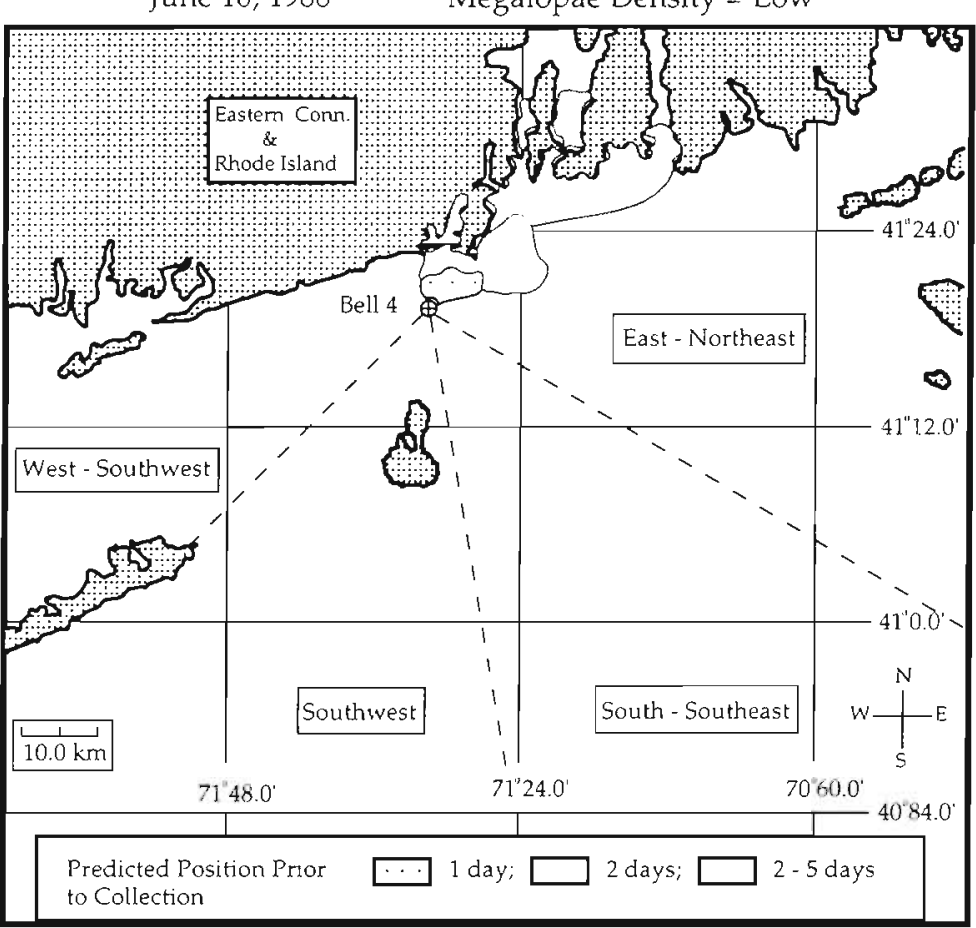

short time period would be that the previous plankton:c stage of the rock crab (stage $V$ zoea) exhibit a synchronized metamorphosis. In order for this mechanism to occur, there should be some behavioral or physiological linking of megalopae with the environment or each other A related study detected no significant relationship between the timing of settlement by megalopae and the lunar cycle or the habitat in which they settled (Clancy 1995). We believe it is unlikely for this population to settle randomly while undergoing a synchronous metamorphosis from stage $\mathrm{V}$ zoea to the megalopal stage.

The results of the receptor-mode trajectory simulations further support the suggestion of exogenous production and shoreward transport of rock crab megalopae. These results indicate a clear and consistent effect of wind and tidal advection on subsequent catch of megalopae, regardless of drift factor (Table $2 a, b$ ). This relationship is especially clear when one examines the days of 'high' (>10 megalopae $\mathrm{m}^{-3}$ ) abundance (Table 2a). From these results, then, we argue that advection by wind and tides is responsible for delivery of rock crab megalopae to the sampling area.

The relationship between advection and planktonic density has been documented in a variety of organisms. For crustaceans, the mechanism driving this relationship may be wind-driven surface transport (McConnaughey et al. 1992, 1994, Hudon \& Fradette 1993), a combi-

Fig. 2. Predicted transport of rock crab Cancer irroratus, megalopae using the receptor-mode trajectory capability of OILMAP on (a) a high abundance day and (b) a low abundance day. The high abundance simulation, which was defined as $>10$ megalopae $\mathrm{m}^{-3}$, was begun on 24 June 1992 while the low abundance simulation, defined as $<10$ megalopae $\mathrm{m}^{-3}$, was started on 10 June 1988. The predicted source location for 3 time periods, 1,2 and $5 \mathrm{~d}$ prior to collection, are each indicated as a shaded area. Shaded areas located to the south and west of Bell 4 indicate onshore transport and shaded areas to the north and east of Bell 4 an offshore transport. Dotted lines that intersect Bell 4 were used to judge into which region a single receptor-mode trajectory simulation would be grouped 
nation of swimming and wind-driven transport (Katz et al. 1994), subtidal advection (Epifanio et al. 1989) or shoreward advection by internal waves (Shanks 1983, 1985, 1986, 1988). Indeed for southern New England, high concentrations of American lobster larvae were correlated with onshore winds (Fogarty 1983); these patterns may have been affected by larval behavior (Katz et al. 1994). Small-scale distribution patterns of plankton are also influenced by hydrographic features such as coastal fronts (Zeldis \& Jillet 1982). The relationship between advection and planktonic abundance also exists in coral reef and temperate fish populations (e.g. Rothschild 1986, Milicich 1994, Milicich \& Doherty 1994, Schultz \& Cowen 1994). Large scale oceanographic features, such as the intensity of the subtropical counter current near Hawaii, are also thought to affect transport of spiny lobster Panulirus marginatus postlarvae (Polovina \& Mitchum 1992).

Results of this research indicate a relationship between shoreward transport and subsequent catch of rock crab megalopae. The magnitude of megalopal transport is determined by drift factor, and in this study we used 2 drift factors ( $D F=3.5$ and $1.75 \%$ of wind speed). We consider the first drift factor to be a high estimate $(3.5 \%$ is a typical value to model drift of oil) with the lower value $(D F=1.75 \%$ ) meant to approximate drift under lower advective conditions (ASA 1993). Drift factor, though, should only affect the magnitude of transport and not the direction of transport.

However the second variable, angle of drift relative to wind, can directly affect the direction of transport. In this paper we used a $0^{\circ}$ drift angle for all simulations believing this to be a valid first approximation in the shallow waters of Block Island Sound. If the study area were deep (i.e. several hundred meters), then the angle of transport should be oriented to the right of the wind (in the Northern Hemisphere) due to Ekman transport (Knauss 1978). Our study area is shallow, often less than $30 \mathrm{~m}$ deep, and its hydrography does not meet the conditions of classic Ekman theory. Direct observations suggest that the Ekman spiral degrades under the influence of the bottom in shallow water (Faller 1971). Under conditions of high wind and fully developed seas, shallow water depths retard the movement of material away from a $0^{\circ}$ drift angle (Youssef 1993, Youssef \& Spaulding 1993). In the west passage of Narragansett Bay, Weisberg (1972) concluded that the direction of transport was dominated by wind events of 2 to $3 \mathrm{~d}$ in duration. Under the shallow water conditions of Weisberg's (1972) study, and presumably such as those found in our study area, net transport was found to be seaward (southerly) or landward (northerly) in direct response to wind direction.

Another mechanism to promote downwind transport is langmuir circulations, which form roughly parallel

\section{Abundance $=$ High \\ Drift Factor $=3.5 \%$; Drift Angle $=0^{\circ}$}

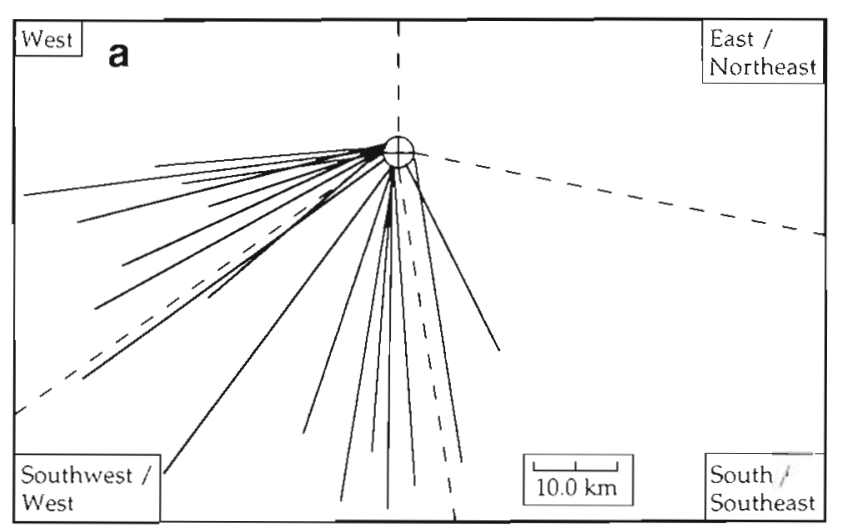

Abundance $=$ Low

Drift Factor $=3.5^{\circ}$; Drift Angle $=0^{\circ}$

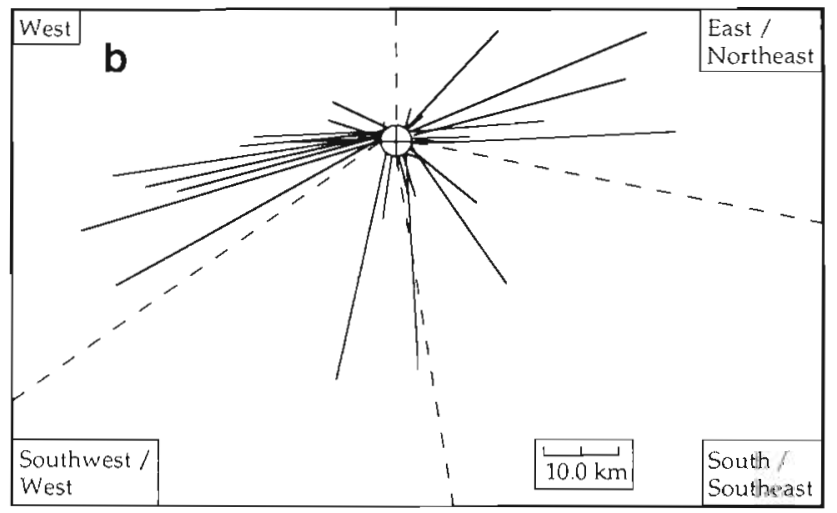

Fig. 3. Average predicted transport vectors obtained from OLLMAP simulations during high $\left(>10\right.$ megalopae $\mathrm{m}^{-3}$ ) and low $\left(<10\right.$ megalopae $\mathrm{m}^{-3}$ ) neustonic megalopae abundance and high drift factor $(D F=3.5 \%$ ) in Block Island Sound, Rhode Island. Circle with cross-hairs represents the location of the sampling region. Each vector represents the average transport direction of a single simulation. Dotted lines indicate separation between adjacent regions. See Fig. 2 for more detail

$\left( \pm 15^{\circ}\right)$ to the direction of the wind under low wind speeds (Leibovich 1983, Shanks 1995). There is preliminary evidence that langmuir cells are coherent even under higher wind speeds (Hamner \& Schneider 1986). These small-scale hydrographic features produce circulation patterns that prevent particle movement to the right of the wind while also retarding downward advection; the path of a particle in a langmuir cell is similar to a corkscrew, so advection is approximately downwind (i.e. $\approx 0^{\circ}$ ) (Leibovich 1983, Hamner \& Schneider 1986, Shanks 1995).

We believe that the results of this paper are robust. If transport at some angle to the right of the wind does occur, it is unlikely to change the main message of this 
research: during the $8 \mathrm{yr}$ time series, our analyses indicated that onshore transport produces high pulses of megalopae, while under conditions of offshore transport, high megalopae abundance was never recorded. Also, if 2-layered estuarine flow is present in our study area, despite the evidence of Weisberg (1972) to the contrary, rock crab megalopae would not be prevented from utilizing wind and tidal advection at the surface to enhance their recruitment.

The proposed recruitment mechanism should have dramatic implications to the benthic demography of the local rock crab population. Over our 8 yr time series, there was consistently high megalopal delivery to the sampling area and, we presume, to any of the southward facing shores in the Southern New England region. Northward transport by wind and tides should be a major component of the rock crab's recruitment strategy. A test for whether wind-driven recruitment is important to the local rock crab population in this region would be to compare direction of transport and recruitment to the benthos to adult abundances at appropriately lagged times. From the results of this work we conclude that years of high shoreward transport should result in increased juvenile and adult abundance levels.

Acknowledgements. This research was part of a $\mathrm{PhD}$ dissertation from the University of Rhode Island for M.C. Sample collection and counting could not have been accomplished without the aid of many graduates and undergraduates throughout the years. This research was supported by several research grants from Rhode Island SeaGrant and NOAA through their CMER program. Early drafts of this manuscript were greatly improved by comments from Mike Fogarty M.C. thanks Applied Science Associates, especially Malcolm Spaulding, Eoin Howlett and Henry Rines, for making OILMAP accessible and furnıshing computers to do model runs; they (ASA) were also critical in making this manuscript more clear. We also thank the anonymous reviewers for their comments

\section{LITERATURE CITED}

ASA (1993) User's manual for OlLMAP, Version 3.0. Applied Science Associates, Narragansett, RI

Beauchamp CH, Spaulding ML (1978) Tidal circulation in coastal seas. Proc Spec Conf Ver Math Phys Models Hydraulic Eng Amer Soc C Eng, p 518-528

Carriker ML (1951) Ecological observations on the distribution of oyster larvae in New Jersey estuaries. Ecol Monogr $21: 19-38$

Chesson PL (1986) Environmental variation and the coexistence of species. In: Diamond J, Case TJ (eds) Community ecology. Harper \& Row Publishers, New York, p 240-256

Clancy M (1995) Settlement and early benthic distribution patterns in the rock crab, Cancer irroratus. PhD dissertation, University of Rhode Island, Kingston

Cobb JS, Wang D, Campbell DB, Rooney P (1989) Speed. and direction of swimming by postlarvae of the American lobster, Homarus americanus. Trans Am Fish Soc 118:82-86
Epifanio CE, Masse AM, Garvine RW (1989) Transport of blue crab larvae by surface currents off Delaware Bay, USA. Mar Ecol Prog Ser 54:35-41

Faller AJ (1971) Oceanic turbulence and the langmur circulations. Annu Rev Ecol Syst 2:201-236

Fogarty MJ (1983) Distribution and relative abundance of American lobster, Homarus americanus, larvae: New England investigations during 1974-1979. NOAA Tech Rep SSRF 775:3-61

Fogarty MJ, Sissenwine MP, Cohen EB (1991) Recruitment variability and the dynamics of exploited marine populations. Trends Ecol Evol 6(8):241-246

Forward RB Jr, Rittschof D (1994) Photoresponses of crab megalopae in offshore and estuarine waters: implications for transport. J Exp Mar Biol Ecol 182:183-192

Hamner WM, Schneider D (1986) Regularly spaced rows of medusae in the Bering Sea: role on langmuir circulation Limnol Oceanogr 31(1):171-176

Hines AH (1991) Fecundity and reproductive output in nine species of Cancer crabs (Crustacea, Brachyura, Cancridae). Can J Fish Aquat Sci 48(2):267-275

Hudon $C_{1}$ Fradette $\mathrm{P}$ (1993) Wind-induced advection of larval decapods into Baie de Plaisance (Iles de la Madeleine. Quebec). Can J Fish Aquat Sci 50:1422-14:34

Johnson DR, Hester BS (1989) Larval transport and its association with recruitment of blue crabs to Chesapeake Bay. Estuar Coast Shelf Sci 28:459-472

Katz CH, Cobb JS, Spaulding M (1994) Larval behavior hydrodynamic transport, and potential offshore-to-inshore recruitment in the American lobster. Homarus americanus. Mar Ecol Prog Ser 103:265-273

Knauss JA (1978) Introduction to physical oceanography. Prentice-Hall Inc, Englewood Cliffs, NJ

Leibovich S (1983) The form and dynamics of langmuir circulations. Annu Rev Fluid Mech 15:391-428

McConnaughey RA, Armstrong DA, Hickey BN. Gunderson DR (1992) Juvenile dungeness crab (Cancer magister) recruitment variability and oceanic transport during the pelagic larval phase. Can J Fish Aquat Sci 49:2028-2044

McConnaughey RA, Armstrong DA, Hickey BM, Gunderson DR (1994) Interannual variability in coastal Washington Dungeness crab (Cancer magister) populations: larval advection and the coastal landing strip. Fish Oceanogr 3 $22-38$

Milicich M (1994) Dynamic coupling of reef fish replenishment and oceanographic processes. Mar Ecol Prog Ser 110:135-144

Milicich M, Doherty PJ (1994) Larval supply of coral reef fish populations: magnitude and synchrony of replenishment of Lizard Island. Great Barrier Reef. Mar Ecol Prog Ser 110:121-134

Palmer AR, Strathmann RR (1981) Scale of dispersal in vary. ing environments and its implications for life histories of marine invertebrates. Oecologia 48:308-318

Phillips BF, McWilliam PS (1986) The pelagic phase of spiny lobster development. Can J Fish Aquat Sci 43:2153-2163

Polovina JJ, Mitchum GT (1992) Variability in spiny lobster Panulirus marginatus recruitment and sea level in the Northwestern Hawaiian Islands. Fish Bull 90:483-493

Reilly PN, Salla SB (1978) Biology and ecology of the rock crab, Cancer irroratus, Say, 1817, in southern New England waters (Decapoda, Crustacea). Crustaceana 34: $121-140$

Rooney P, Cobb JS (1991) Etfects of time of day, water temperature and water velocity on swimming by postlarvae of the Amencan lobster, Homarus americanus. Can J Fish Aquat Sci 48:1944-1950 
Rothschild B (1986) Dynamics of marine fish populations. Harvard University Press, Cambridge, MA

Roughgarden J, Iwasa Y, Baxter C (1985) Demographic theory for an open marine population with space-limited recruitment. Ecology 66(1):54-67

Roughgarden J, Gaines S, Possingham H (1988) Recruitment dynamics in complex life cycles. Science 241:1460-1466

Sastry AN (1977) The larval development of the rock crab, Cancer irroratus, Say, 1817, under laboratory conditions (Decapoda: Brachyura). Crustaceana 32(2):155-168

Scheltema RS (1968) Dispersal of larvae by equatorial currents and its importance to the zoogeography of shoalwater tropical species. Nature 217:1159-1162

Scheltema RS (1986) On the dispersal and planktonic larvae of benthic marine invertebrates: an eclectic overview and summary of problems. Bull Mar Sci 39:290-322

Schultz ET, Cowen RK (1994) Recruitment of coral-reef fishes to Bermuda: local retention or long-distance transport? Mar Ecol Prog Ser 109:15-28

Shanks AL (1983) Surface slicks associated with tidally forced internal waves may transport pelagic larvae of benthic invertebrates and fishes shoreward. Mar Ecol Prog Ser 13: $311-315$

Shanks AL (1988) Further support for the hypothesis that internal waves can cause shoreward transport of larval invertebrates and fish. Fish Bull 86(4):703-714

Shanks AL (1995) Mechanisms of cross-shelf dispersal of larval invertebrates. In: McEdward L (ed) Ecology of marine invertebrate larvae. CRC Press, New York, p 323-368

Sokal RR, Rohlf FJ (1981) Biometry. WH Freeman, New York

This article was presented by K. Sherman (Senior Editorial Advisor), Narragansett, Rhode Island, USA
Spaulding ML (1988) A state-of-the-art review of oil spill trajectory and fate modeling. Oil Chem Pollut 4:39-55

Stehilk LL, MacKenzie CL Jr, Morse WW (1991) Distribution and abundance of four brachyuran crabs on the Northwest Atlantic shelf. Fish Bull 89:473-492

Stoner DS (1990) Recruitment of a tropical colonial ascidian: relative importance of pre-settlement vs post-settlement processes. Ecology 71(5):1682-1690

Sulkin SD (1984) Behavioral basis of depth regulation in the larvae of brachyuran crabs. Mar Ecol Prog Ser 15:181-205

Thorson G (1950) Reproductive and larval ecology of marine bottom invertebrates. Biol Rev 25:1-45

Weisberg RH (1972) The net circulation in the west passage of Narragansett Bay. MS thesis, University of Rhode Island, Kingston

Williams AB (1984) Shrimps, lobsters and crabs of the Atlantic coast of the eastern United States, Maine to Florida Smithsonian Institute Press, Washington, DC

Young CR (1989) Selection of predator-free settlement sites by larval ascidians. Ophelia 30(2):131-140

Youssef $M$ (1993) The behavior of the near ocean surface under the combined action of waves and currents in shallow water. PhD dissertation, University of Rhode Island, Kingston

Youssef M, Spaulding M (1993) Drift current under the action of wind and waves. 16th Arctic and Marine Oil Spill Program, Technical Seminar. American Petroleum Institute, Calgary, Alberta

Zeldis JR, Jillet JB (1982) Aggregation of pelagic Munida gregaria (Fabricius) (Decapoda, Anomura) by coastal fronts and internal waves. J Plankton Res 4:839-857

Manuscript first recelved: April 15, 1996

Revised version accepted: March 12, 1997 